\title{
Understanding the clinical dilemmas that shape medical students' ethical development: questionnaire survey and focus group study
}

\author{
Lisa K Hicks, Yulia Lin, David W Robertson, Deborah L Robinson, Sarah I Woodrow
}

During the past 30 years new medical technologies and public concern about medical ethics have led medical schools in Europe and North America to increase their teaching of formal ethics considerably. Most of this teaching focuses on dilemmas that students may face in their future practice, rather than the ethical problems they encounter as medical students. Several studies and editorials suggest that students' clinical experiences constitute an informal or "hidden" ethics curriculum, ${ }^{1}$ which can undermine their developing professionalism. Clinical teachers who act as negative role models, especially those who show unethical behaviour towards patients, is the most frequently cited problematic aspect of this hidden curriculum. ${ }^{1-5}$ Previous studies have focused on the prevalence of ethical dilemmas as perceived by students, rather than the nature of the dilemmas that students encounter. ${ }^{45}$ Our study's premise was that the prevalence and the nature of medical students' ethical dilemin resolving them.

\section{Methods and results}

We surveyed 108 clinical students (90\% response rate) who were about one year away from completing medimas need to be recognised and understood as a first step

cal school at the University of Toronto. We asked them to report how often they had been placed in a clinical situation in which they had felt pressure to act unethically. Nearly half $(47 \% ; 48 / 103)$ of students reported that this had happened to them very frequently, frequently, or occasionally. When asked to rate how often they had witnessed a clinical teacher acting unethically, $61 \%(62 / 102)$ of students reported that this had happened to them very frequently, frequently, or occasionally.

Having ascertained that students encountered ethically problematic situations in their clinical training, we held four focus groups with 20 clinical students who were one year from completing medical school. Our content analysis of the focus groups revealed three categories of ethically problematic situations: conflict between the priorities of medical education and those of patient care, responsibility beyond a student's capacities, and involvement in patient care perceived to be substandard (table).

Finally, in the focus groups, students reflected that the ethical problems they encountered were seldom discussed or resolved with clinical teachers. For instance, one medical student described a situation in which a number of medical students were disturbed by

Types of ethical dilemmas faced by students, with examples and quotations from focus groups

\begin{tabular}{|c|c|c|}
\hline $\begin{array}{l}\text { Type of ethical dilemma } \\
\text { (No of students } \\
\text { reporting the problem) }\end{array}$ & Examples & Illustrative quotations from students \\
\hline \multirow[t]{4}{*}{$\begin{array}{l}\text { Conflict between medical } \\
\text { education and patient } \\
\text { care (17) }\end{array}$} & $\begin{array}{l}\text { - Patients asked to return to clinic for follow up visits } \\
\text { and not informed that the visits were entirely for } \\
\text { teaching purposes }\end{array}$ & \multirow{4}{*}{$\begin{array}{l}\text { Once, when I was on call, there was a patient who was palliative, in a } \\
\text { vegetative state. The resident [house officer] I was working with decided that } \\
\text { this would be a good opportunity for me to learn how to do a femoral stab, } \\
\text { even though it was not necessarily medically required. The patient was not } \\
\text { expected to [recover] from his current condition, and wasn't in a position to } \\
\text { argue, and I think there was a very thinly veiled excuse that we could do it. It } \\
\text { was more or less for the exercise in education on a non-consenting patient. It } \\
\text { struck me as so at the time too, but we don't really get a lot of opportunity to } \\
\text { practise those types of procedures. }\end{array}$} \\
\hline & $\begin{array}{l}\text { - House officer instructed a student to perform a } \\
\text { femoral puncture, for purely educational reasons, on a } \\
\text { comatose patient who did not need the procedure }\end{array}$ & \\
\hline & $\begin{array}{l}\text { - Students asked to perform pelvic examinations on } \\
\text { patients under general anaesthesia without patients' } \\
\text { prior consent }\end{array}$ & \\
\hline & $\begin{array}{l}\text { - Patient's name and details of care discussed by staff } \\
\text { and students in a public place }\end{array}$ & \\
\hline \multirow{4}{*}{$\begin{array}{l}\text { Responsibility exceeding } \\
\text { student's capabilities } \\
\text { (15) }\end{array}$} & $\begin{array}{l}\text { - Student completed antenatal visits with patients who } \\
\text { were never seen by a doctor }\end{array}$ & \multirow{4}{*}{$\begin{array}{l}\text { I had one [an ethical dilemma] on obstetrics, being asked to go get a consent } \\
\text { for a dilatation and curettage. I was on call at a peripheral hospital on the } \\
\text { weekend. No resident; just the staff [consultant]. The staff wasn't the most } \\
\text { cooperative. And so I went and did it. But I checked with the patient: "Did the } \\
\text { staff talk with you about the complications and the risks and the expectations? } \\
\text { Because, frankly, I would not be capable of doing that." The patient said "Yes, } \\
\text { yes, yes," and I documented that I didn't do the discussion [and that] the staff } \\
\text { did the discussion. And on the consent [form] I put my name and "CC3" } \\
\text { [denoting medical student status] in big letters after it, but I still thought it was } \\
\text { ridiculous. }\end{array}$} \\
\hline & $\begin{array}{l}\text { - House officer refused to respond to student's } \\
\text { request for help in assessing an unstable patient }\end{array}$ & \\
\hline & $\begin{array}{l}\text { - Student and house officer left by teacher to close a } \\
\text { wound, without knowing how to close it properly }\end{array}$ & \\
\hline & $\begin{array}{l}\text { - Student expected to give weekly psychotherapy } \\
\text { sessions without supervision }\end{array}$ & \\
\hline \multirow[t]{4}{*}{$\begin{array}{l}\text { Involvement in care } \\
\text { perceived to be } \\
\text { substandard (9) }\end{array}$} & $\begin{array}{l}\text { - Student witnessed house officer responding } \\
\text { inappropriately to patient's refusal to have joint } \\
\text { aspiration; consent form completed, but consent not } \\
\text { meaningfully given }\end{array}$ & \multirow{4}{*}{$\begin{array}{l}\text { On my medical rotation, there was a patient on the floor who had lung cancer } \\
\text { but [the physicians] weren't sure [of the type]. Nobody would tell the patient } \\
\text { that he had cancer. The pathology report said that it was very suspicious for } \\
\text { malignant cells. Anyone with any sort of medical training would know that the } \\
\text { chances of it being malignant were very high. [Yet] nobody talked to the } \\
\text { pathologist to find out what information they could tell the patient based on } \\
\text { that. I asked the pathologist afterwards, and it was very clear that the patient } \\
\text { could have been told he had cancer but they just didn't know exactly what type } \\
\text { it was and they didn't want to get into specifics until they knew that every test } \\
\text { had been done. This patient was probably in the hospital close to a week and a } \\
\text { half and, every time I would go in the room, he would keep saying to me, "I } \\
\text { don't have cancer do I?" And I was not at liberty to even tell him anything } \\
\text { because the staff and the respirologist wouldn't tell him. }\end{array}$} \\
\hline & $\begin{array}{l}\text { - Student instructed by house officer to repair a child's } \\
\text { scalp laceration with inappropriate supplies }\end{array}$ & \\
\hline & $\begin{array}{l}\text { - Patient requested a narcotic-free vaginal delivery but } \\
\text { given intravenous narcotics without her knowledge }\end{array}$ & \\
\hline & $\begin{array}{l}\text { - Student uncomfortable about inadequate pain relief } \\
\text { in patient care; felt it was 'constantly put off' by house } \\
\text { officer }\end{array}$ & \\
\hline
\end{tabular}

\section{Editorial by Doyal Personal view $\mathrm{p} 743$ University of Toronto Faculty of Medicine, Toronto, Canada M5S 1A8 \\ Lisa K Hicks* house officer \\ Yulia Lin \\ house officer \\ David W Robertson medical student \\ Sarah I Woodrow house officer \\ *Authors are listed in alphabetical order because they made equal contributions to this work. \\ University of Western Ontario, Faculty of Medicine, London, Ontario, Canada N6A 5B8 \\ Deborah L Robinson house officer \\ Correspondence to: D Robertson, \\ 8 Clarence Square, Toronto, Canada M5V 1H1 davidw.robertson@ utoronto.ca}

BMJ 2001;322:709-10 
a situation they encountered, but felt powerless to resolve it.

"We were in seeing the patient and there were four medical students in there and this girl had already sat through an hour with me going through a complete history and physical. And then, the staff [clinical teacher] decided that he would use her for the rest of the two hours for all of us to do the exam on her and she had no idea why we were there ... One of the medical students was looking at her fundi and he couldn't see them. So, the staff was yelling, "Any idiot can see the optic fundus. How can you not see it? I can see it. Look! Why can't you see it?" Then he said, "I want each and every one of you to keep looking until you see it." So the poor girl is getting blinded by four of us trying to see her fundi ... He was just so inappropriate, the poor girl was almost in tears ... We were all very intimidated; we thought it was inappropriate and we all talked about it later, but he [the clinical teacher] put us all in a position where we were scared to death of him. We were afraid to say anything [although] he was probably wrong."

\section{Comment}

Previous research indicates that medical students experience ethical dilemmas concerning patient care; our study confirms this and goes further by identifying three types of ethical dilemma characteristic of early clinical training. It also suggests that these dilemmas are seldom resolved during medical school. We hope that by learning to recognise and explore these ethical dilemmas medical educators will be able to expose, and ultimately dismantle, deleterious aspects of the "hidden curriculum" which currently hinder the ethical growth of medical students.

Dr Sophia Ahmed helped conceive the study and carry out the survey, and Dr April Boyd helped with statistical analysis. Dr Peter Singer, Dr Philip Hébert, and Walter Atkins advised the authors or commented on drafts of this paper.

Contributors: All five authors conceived and carried out the study, analysed the data from the survey and focus groups, and wrote the manuscript. DWR is the guarantor.

Funding: Faculty of Medicine, University of Toronto.

Competing interests: None declared.

1 Hafferty FW, Franks R. The hidden curriculum, ethics teaching, and the structure of medical education. Acad Med 1994;69:861-71.

2 Swenson SL, Rothstein JA. Navigating the wards: teaching medical students to use their moral compasses. Acad Med 1996;71:591-4.

3 St Onge J. Medical education must make room for student-specific ethical dilemmas. Can Med Assoc J 1997;156:1175-7.

4 Bisonette R, O'Shea RM, Horwitz M, Route CF. A data-generated basis for medical ethics education: categorizing issues experienced by students during clinical training. Acad Med 1995;70:1035-7.

5 Feudtner C, Christakis DA, Christakis NA. Do clinical students suffer ethical erosion? Students' perceptions of their ethical and personal development. Acad Med 1994:69:670-9.

(Accepted 17 November 2000)

\title{
Sex differences in speed of emergence and quality of recovery after anaesthesia: cohort study
}

\author{
Paul S Myles, Andrew D M McLeod, Jennifer O Hunt, Helen Fletcher
}

Department of Anaesthesia and Pain Management, Alfred Hospital, Prahran, Victoria 3181, Australia Paul S Myles head of research Andrew D M McLeod specialist registrar Jennifer O Hunt clinical trials coordinator

Helen Fletcher research nurse Correspondence to: P S Myles p.myles@alfred. org.au

BMJ 2001;322:710-1
Recent evidence shows that postoperative recovery may differ between men and women. ${ }^{12}$ We planned a prospective cohort study to examine the impact of gender on postoperative outcome. This was associated with a trial investigating the effectiveness of several anaesthetic regimens. ${ }^{3}$

\section{Participants, methods, and results}

After obtaining ethics committee approval and informed consent, we studied 463 adult patients undergoing elective inpatient surgery. An observer experienced in postoperative review followed up all patients daily until the third postoperative day. The primary end point was quality of recovery, as measured by a quality of recovery score consisting of nine (range $0-18$ ) items. ${ }^{4}$ Secondary end points included recovery times and the incidence of complications (postoperative nausea and vomiting, headache, backache, and sore throat).

Data were analysed using $t$ tests or generalised linear models (to adjust for the covariates of patients' age, American Society of Anesthesiologists status, and extent and duration of surgery). Associations were described using $\chi^{2}$, risk ratios, and 95\% confidence intervals. Cox proportional hazards was used to adjust for the covariates to identify the effect of gender on the pattern of recovery.

The men $(n=241)$ and women $(n=222)$ in our study were similar in terms of age, American Society of Anesthesiologists physical status, and type, duration, and extent of surgery. Women were more likely to have a history of postoperative nausea and vomiting (42 $(19 \%)$ women $v 18(7.4 \%)$ men, $\mathrm{P}<0.001)$ and to have received prophylactic antiemetic agents (102 (46\%) women $v 70(29 \%)$ men, $\mathrm{P}<0.001)$.

Women emerged significantly more quickly than men (table), and overall quality of recovery was worse (quality of recovery score averaged over time: women 15.7 (95\% confidence interval 15.6 to 16.0$)$; men 16.3 (16.2 to 16.5$) ; \mathrm{P}=0.024)$. Women had a slower return to baseline health status, as determined by their quality of recovery score (hazard ratio 0.75 (0.59 to 0.95 ), $\mathrm{P}=0.005$ ), and were more likely to have postoperative complications (table). All these findings were similar when analysed separately for each anaesthetic regimen and type of surgery (results not shown).

\section{Comment}

We found that women emerged more quickly than men from general anaesthesia but had a 25\% slower rate of return to their preoperative health status. They 